\title{
The Legal and Social Aspect for Underage Marriage Women's Education Rights in the Perspective of Human Rights: Contemporary Issues and Problems
}

\author{
Ridwan Arifin, ${ }^{1}$ Rodiyah, ${ }^{2}$ \\ Fadhilah Rizky Afriani Putri ${ }^{3}$ \\ 1,2 Universitas Negeri Semarang (UNNES), \\ Semarang - Indonesia, ${ }^{3}$ Women and Child \\ Protection Forum - Indonesia
}

Corresponding Author: Ridwan Arifin, email: ridwan.arifin@mail.unnes.ac.id; Sekaran, Kec. Gn. Pati, Kota Semarang 50229

\begin{abstract}
The right to education is a fundamental human right and must be fulfilled by the state. However, the right to education, especially for women with underage marriages (child marriages), has not yet had adequate education. This paper aims to analyze the legal and social aspects of children's educational rights, especially women with conditions of underage marriage (child marriage) in Indonesia. This study examines the formal juridical aspects of the protection and guarantee of education rights for women and social aspects related to the constraints of fulfilling women's education. This research is a normative juridical study in which this study looks at the community's various facts based on the applicable legal rules. This research's social aspects are seen based on various social theories related to this research study; the data and facts obtained in this study are data sourced from previous research, both print and online media. This research confirms that child marriage is motivated by many factors, one of which is economic conditions so that women cannot achieve the rights to education. However, according to the 1945 Constitution Article 31 paragraph (1) that every citizen has the right to get an education. However, there are no strict criminal sanctions for families who leave their children out of school in terms of law enforcement.
\end{abstract}

Keywords: right to education; child education rights; child protection: underage marriage

\begin{abstract}
Abstrak: Hak atas pendidikan adalah hak asasi manusia yang fundamental dan harus dipenuhi oleh negara. Namun hak atas pendidikan, khususnya bagi perempuan dengan kawin di bawah umur (kawin anak), belum memiliki pendidikan yang memadai. Makalah ini bertujuan untuk menganalisis aspek hukum dan sosial dari hak pendidikan anak, khususnya perempuan dengan kondisi perkawinan di bawah umur (perkawinan anak) di Indonesia. Kajian ini mengkaji aspek yuridis formal perlindungan dan jaminan hak pendidikan bagi perempuan dan aspek sosial terkait dengan kendala pemenuhan pendidikan perempuan. Penelitian ini merupakan kajian yuridis normatif dimana kajian ini melihat berbagai fakta masyarakat berdasarkan aturan hukum yang berlaku. Aspek sosial penelitian ini dilihat berdasarkan berbagai teori sosial yang berkaitan dengan kajian penelitian ini; data dan fakta yang diperoleh dalam penelitian ini merupakan data yang bersumber dari penelitian sebelumnya,
\end{abstract}


baik media cetak maupun online. Hasil penelitian ini menegaskan bahwa perkawinan anak dilatarbelakangi oleh banyak faktor, salah satunya adalah kondisi ekonomi yang menyebabkan perempuan tidak dapat memperoleh hak atas pendidikan. Namun menurut UUD 1945 Pasal 31 ayat (1) bahwa setiap warga negara berhak mengenyam pendidikan. Namun, tidakada sanksi pidana yang tegas bagi keluarga yang meninggalkan anaknya tidak bersekolah dalam hal penegakan hukum.

Kata Kunci: hak memperoleh pendidikan; hakanak memperoleh pendidikan; perlindungan anak; pernikahan di bawah umur

\section{A. Introduction}

The high case of underage Marriage in Indonesia makes this problem a severe problem. Not only the issue of child marriage but in many cases is closely related to human rights and violations of children's rights, and even acts of violence and human trafficking. Based on data from the Central Statistics Agency (BPS), the prevalence of child marriage shows a very alarming number, where 1 in 4 or 23 percent of girls in Indonesia marry when they are children. Every year around 340 thousand girls marry under the age of 18. In 2017, the percentage of child marriages had reached 25.17 percent. $^{1}$ The Supreme Court Working Group noted the number of child marriages in Indonesia is still high. In 2018, the number of child marriages in the country reached 193 thousand cases. The same thing was also revealed by data from the Ministry of Women's Empowerment and Child Protection (KPPPA) that said one in six girls in Indonesia married before 18. KPPPA also notes that every year 340,000 girls marry before they turn 18 in Indonesia. ${ }^{2}$

Moreover, child marriage cases violate many children's rights in the human context as a creation of God and human rights, ${ }^{3}$ where humans are recognized as

\footnotetext{
${ }^{1}$ M. Reza Sulaiman and Risna Halidi, "Perkawinan Anak, Catatan Hitam di Hari Anak Perempuan Internasional 2019," suara.com, October 11, 2019, https://www.suara.com/ health/2019/10/11/061500/perkawinan-anak-catatan-hitam-di-hari-anak-perempuaninternasional?page=all.

2Muhammad Syahrianto, "Belum Turun, Jumlah Perkawinan Anak di Indonesia Masih di Angka 193 Ribu Kasus," Warta Ekonomi, February 1, 2020, https://www.wartaekonomi .co.id/read269607/belum-turun-jumlah-perkawinan-anak-di-indonesia-masih-di-angka-193-ribukasus;; Maya Saputri, "KPPPA: Satu dari Enam Anak Perempuan Indonesia Menikah Usia Dini," tirto.id (Tirto, September 19, 2019), https://tirto.id/kpppa-satu-dari-enam-anak-perempuanindonesia-menikah-usia-dini-ehS4.

${ }^{3}$ Nurhidayatuloh Nurhidayatuloh and Leni Marlina, "Perkawinan di Bawah Umur Perspektif HAM: Studi Kasus di Desa Bulungihit, Labuhan Batu, Sumatra Utara," Al-Mawarid Journal of Islamic
} 
the perfect creatures of God created in the best possible form. Human beings are also social beings who always need other human beings to live their lives to complete their physical and spiritual needs so that humans cannot live without connecting with other people. Because of these physical and spiritual needs, humans have a desire to live together regularly. One way to tie such a relationship is by marriage. Marriage is a serious commitment between couples and weddings, signifying the inauguration of their relationship recognized by the community. ${ }^{4}$ Marriage can complement the biological needs that exist in humans. Marriage is a bond of birth and heart between two humans, men and women, who have a goal to live together forever, happily and eternally. ${ }^{5}$ A good marriage is a legitimate and not underhanded marriage because marriage is a sacred, healthy, and strong agreement to live together legally between a man and a woman to form an eternal, loving, loving, peaceful, and happy family.

In some people's lives, marriage means that men and women are adults. Marriage will change all their life forms and start building a new life or creating a new family. ${ }^{6}$ Marriage is a significant and sacred event for some people, so it is essential to prepare everything needed for Marriage from all aspects such as physical, mental, and also socio-economic aspects. Marriage will make a family, which is the smallest unit that becomes the primary foundation for the continuity and development of a nation and state society. Because the family is the first unit for children who will later be the successor to the nation, the family must be the first right place for their children to achieve a bright future.

Marriage cannot be separated from the rules or provisions that apply, be it religious law, customary law, or statutory law. Increasing population growth, indeed, legislation that regulates marriage is needed so that marriage can support the development's success. Article 1 of Law Number 1 of 1974 concerning

Law 11, no. 2 (2011): 211-24; Mesha Mediani, "Pernikahan Dini dan Persoalan Hak Anak yang tak Terlindungi," CNN Indonesia, April 18, 2018, https://www.cnnindonesia.com/nasional/ 20180418100224-20-291626/pernikahan-dini-dan-persoalan-hak-anak-yang-tak-terlindungi; Editor Kompas, "Pernikahan Dini, Bentuk Pelanggaran HAM," Kompas, January 28, 2009, https://internasional.kompas.com/read/2009/01/28/19315957/Pernikahan.Dini.Bentuk.Pelangg aran.HAM.

${ }^{4}$ Marmiati Mawardi, "Problematika Perkawinan di Bawah Umur," Analisa 19, no. 2 (2012): 201-12, https://doi.org/10.18784/analisa.v19i2.166.

${ }^{5}$ Rahmatian Rahmatian, “Studi Kasus Perkawinan di Bawah UMur," Al-Daulah: Jurnal Hukum Pidana dan Ketatanegaraan 5, no. 1 (2016): 119-132, https://doi.org/10.24252/ad.v5i1.1447.

${ }^{6}$ Robert Jensen and Rebecca Thornton, "Early Female Marriage in the Developing World," Gender \& Development 11, no. 2 (2003): 9-19, https://doi.org/10.1080/741954311. 
Marriage states that Marriage is a physical bond between a man and a woman as husband and wife to form a happy and eternal family or household based on the One Godhead. Law No. 1 of 1974 concerning Marriage is expected to be a maximum contributor to Indonesia's development.7

Since the enactment of Law No. 1 of 1974 concerning Marriage which was then followed up with Government Regulations (PP No. 9 of 1975), the provisions of the legislation in the case of Marriage, such as regarding the age limits of Marriage (marriage requirements), basically has the aim to anticipate the implementation of marriage at a young age or in other words it is intended as an effort to foster legal awareness that can motivate towards delaying marital age, at least men aged 19 years (nineteen) years and women aged 16 (six-twelve) years. This means that men who are at least 19 years old and women who are at least 16 years old can be legally mated with the state and religion. Article 7 paragraph (2) of Law Number 1 of 1974 concerning marriage states that in this case, it can request dispensation to the court or other officials appointed by both male and female parents. Thus, based on these provisions, the Marriage is held before fulfilling the requirements referred to as the category of underage Marriage or young age marriage, where men and women who want to marry are still very young and have not fulfilled the conditions specified in the marriage. Do marriage. In general, big cities tend to delay the age of marriage, while in villages in Indonesia they generally tend to do underage marriage.

In Indonesia, girls are the most vulnerable victims of child marriages, with prevalence: (1) Girls from rural areas experience twice as much vulnerability to Marriage, (2) The bride of the child who is most likely to come from a low-income family, and (3) Girls who are less educated and drop-out from school are generally more vulnerable to becoming child brides than those who attend school. ${ }^{8}$

Furthermore, the number of child marriages in Indonesia, especially in Central Java Province, is a relatively high one in five children in Central Java get married early; at least there are around 30 thousand cases of child marriage (which propose marriage dispensation). ${ }^{9}$ Moreover, the data showed that the average age of children in Central Java at Marriage is only around 12 years. ${ }^{10}$

\footnotetext{
${ }^{7}$ Law Number 1 of 1974 concerning Marriage (UU No. 1 Tahun 1974 tentang Perkawinan).

8Dewi Candraningrum, "Pernikahan Anak: Status Anak Perempuan," Jurnal Perempuan 21, no. 1 (2016): 4-8.

9Ida Nur Layla, “Satu dari Lima Anak di Jateng Nikah Dini,” Radar Semarang, October 14, 2019, https://radarsemarang.jawapos.com/berita/semarang/2019/10/14/satu-dari-lima-anak-di-
} 
In some previous researches, been shown that child marriage rates in some regions of Central Java are very high, for example, in Rembang District, wherein 2004 the number of early marriages reached 1183 women who were married under the age of 18 years and 44 men who were married under 19 years while for Sedan Sub-district cases of early marriage for women married under 18 years reached 146 people. ${ }^{11}$ Likewise, with Semarang Regency, around 32,000 children have early marriages. Meanwhile, in other regions in Central Java, Pekalongan Regency, in 2017, there are around 2,024 children who have an early marriage. ${ }^{12}$

Children's marriages, these terms are not optimal. Early promotion does not mean that children are involved and pioneered early for people who can be picked up late by others. The term bride and groom glorify the tradition with the term image and celebration. A big slice of this marriage was issued by parents and girls who rarely met them before the wedding. Girls know that they will move to the household, become their legal responsibility, and not see their family or friends for some time. ${ }^{13}$ One of the causes of underage marriage is poverty. Children do objects to sell or marry so that parents are free from economic burdens. ${ }^{14}$ Economic, religious, and social problems are various causes of underage marriage in Indonesia. ${ }^{15}$

Marriage has a problem with the population. It turns out that a low age limit for a woman to marry results in a higher birth rate, in various observations

jateng-nikah-dini-3/; Nidia Zuraya, “KPI: Kasus Perkawinan Anak di Jateng Tinggi,” republika.co.id, November 20, 2017, https://www.republika.co.id/berita/nasional/daerah/17/11/20/ozq2z7383kpi-kasus-perkawinan-anak-di-jateng-tinggi.

${ }^{10}$ Reza Gunadha, "Perempuan di Jawa Tengah Rata-Rata Nikah Usia 12 Tahun," September 16, 2018, https://www.suara.com/news/2018/09/16/165232/perempuan-di-jawa-tengah-rata-ratanikah-usia-12-tahun.

${ }^{11}$ Susi Dwi Maret Tati and Sofwan Indarjo, "Partisipasi Pasangan Pernikahan Dini terhadap Program Keluarga Berencana," Higeia (Journal of Public Health Research and Development) 1, no. 2 (2017): 65-76.

${ }^{12}$ Editor Radar Pekalongan, "Angka Pernikahan Dini di Kota Santri Rangking Tiga se-Jateng," Radar Pekalongan, April 1, 2019, https://radarpekalongan.co.id/65767/angka-pernikahan-dini-dikota-santri-rangking-tiga-se-jateng/.

${ }^{13}$ Nawal M. Nour, “Child Marriage: A Silent Health and Human Rights Issue," Reviews in Obstetrics \& Gynecology 2, no. 1 (2009): 51-66. 2015).

${ }^{14}$ Rika Saraswati, "Hukum Perlindungan Anak di Indonesia" (Bandung: Citra Aditya Bakti,

15Mawardi, "Problematika Perkawinan di Bawah Umur.” 
about the consequences of young marriage. 16 Also, it shows the existence of inharmonious households; even divorce tends to occur. Therefore, Law No. 1 of 1974 concerning Marriage sets the age limit for marrying men and women. As stipulated in Article 7 Paragraph (1), prevention of young marriages means that young marriages do not guarantee happiness, so marriage often ends in divorce. Besides, the absence of maturity in both parties' way of thinking is usually caused by a lack of prior approval from the prospective husband and wife. Such problems are not suitable for marriage according to the Marriage Law Article 1.

Note the provisions of the Marriage Law, which regulates the age limit for marriage not yet effective. It is usually motivated by economic, educational, and socio-cultural (indigenous) factors and free association consequences. Furthermore, children are the younger generation as successors to the ideals of the nation's struggle and human resources for national development. To realize quality human resources in Indonesia capable of leading, maintaining national unity and unity, sustainable development is needed for survival, growth, and physical, mental, and social development and protection from all possibilities that will endanger them and the future of the nation.

In preparing the next generation who are qualified and able to lead, maintain unity and unity, children need to get their education rights. According to Article 28C Paragraph (1) of the 1945 Constitution of the Republic of Indonesia, "Every person has the right to develop themselves through basic fulfillment, the right to education, and to benefit from science and technology, art and culture, to improve their quality of life and for the sake of welfare humanity." Education is the first step for humans in building the future, so that is why every child must get the right to education. Law Number 20 of 2003 concerning the National Education System Chapter IV citizens' rights and obligations of article 5 Paragraph (1) also emphasized that every citizen has the same right to obtain a quality education. Paragraph (2) Citizens who have physical, emotional, mental, intellectual, or social disorders have the right to receive exceptional service education. Paragraph (3) Citizens in remote or underdeveloped areas and remote indigenous peoples have the right to receive exceptional service education. Paragraph (4) Citizens who have potential intelligence and unique talents are entitled to special education. Paragraph (5)

${ }^{16}$ Abdi Koro, Perlindungan Anak di Bawah Umur dalam Perkawinan Usia Muda dan Perkawinan Siri (Bandung: Alumni, 2012). 
Every citizen has the right to have the opportunity to improve lifelong education. Article 6 paragraph (1) every citizen aged seven to fifteen is obliged to attend primary education, and paragraph (2) every citizen is responsible for the continuity of education. The second part of the rights and obligations of parents Article 7 paragraph (1) Parents have the right to choose educational units and obtain information about the development of their children's education. Paragraph (2) Parents of compulsory education children are obliged to provide primary education to their children.

However, if women marry at a young age, they usually do not continue their education. Because when a woman is married, she had to take care of her household, for example, taking care of her husband, her children, and other homework, so it is challenging to continue her education. As well as the stereotypical thinking in Indonesia, the wife only lives behind her husband; education is no longer needed because the wife only stands by her husband. It causes women who marry at a young age to lose their fundamental educational rights, which are very important for their future. Many studies have shown that lack of education will have a more significant negative impact on children because children no longer get the proper education. Because of the lack of education that children can get, they will not become parents who can better educate the next generation. The circle of poverty is even more significant in Indonesia because many children do not get the right to education properly due to underage marriage. Ironically, from several underage marriages, many children are forced to marry underage by their parents. On the grounds, they reduce the family's burden and save his child from the circle of poverty of his family. It also makes the family members not better in the economy and tends to be a worse economy.

This paper examines and analyses the legal and social aspects of underage Marriage, especially concerning children's rights. The article is examining some human rights theories and concepts related to underage marriage. The paper also discusses the education rights for underage Marriage in Indonesia.

\section{B. Legal Aspect of Underage Marriage and Its Limitation: How the Human Rights See this Phenomenon?}

Children who have not reached the age of 18 years or have never married are under the control of their parents as long as they are not revoked from their power. If it has reached the age of 18 years, and it is considered to have grown 
up. If the child has not reached 18 but is married, then the child can no longer be categorized as a child. Based on Law No. 23 of 2002, a child is not 18 years old, including a child who is still in the womb. ${ }^{17}$

Based on Law No. 23 of 2002 concerning Child Protection, children are a mandate and a gift given to humans by the Almighty God, which we must always guard because, in him, the dignity, and rights as human beings must be upheld. Children are the shoots, potentials, and young generation who follow the nation's ideals, which have a strategic role and have unique characteristics and characteristics that guarantee the nation's continuity and state in the future. Therefore, so that the potential of children can grow and develop optimally, both physically, mentally, socially, and behave well, it is necessary to protect their rights, especially in the right to education, because education is the most appropriate place for children's growth and development both physically and psychologically.

From Law No. 23 of 2002 concerning the child's protection, it can be said that the law has a legal politics that is responsive to the protection of children's rights. Children are placed in a noble position as a mandate from God Almighty, who has a strategic role in ensuring this nation's continuity and country. Through Law 23 of 2001, guaranteed child rights are protected; even the Indonesian Child Protection Commission was formed, which has a responsibility to improve the effectiveness of child protection.

Law No. 39 of 1999 concerning Human Rights, arrangements regarding human rights are determined guided by the United Nations Declaration of Human Rights Nation, United Nations Convention on the Elimination of All Form of Discrimination against Women, United Nations Convention concerning Children's Rights, and various other international instruments that regulate concerning human rights. This Act's material is adjusted according to community legal needs and national legal development based on Pancasila and the 1945 Constitution. While inside the 1945 Constitution (amended), a problem regarding human rights was specifically included in Chapter X Articles 28 A to $28 \mathrm{~J}$, which resulted from the Second Amendment of 2000.18

\footnotetext{
${ }^{17}$ Reza Fahlevi, “Aspek Hukum Perlindungan Anak dalam Prespektif Hukum Nasional," Lex Jurnalica 12, no. 3 (2015): 177-91.

18Mukhamad Luthfan Setiaji and Aminullah Ibrahim, "Kajian Hak Asasi Manusia dalam Negara the Rule of Law: Antara Hukum Progresif dan Hukum Positif," Lex Scientia 2, no. 2 (2018): 123-38, https://doi.org/10.15294/lesrev.v2i2.27580.
} 
Furthermore, the marriage of children under the age of 18 is considered a form of state denial of every child's vulnerability and neglect of the right to protect children from all forms of discrimination. When the state opens opportunities for child marriage, things contrary to the state's efforts to fulfill and respect human rights.

At the human rights level, children are recognized as vulnerable groups, in addition to persons with disabilities, minority groups, and pregnant women. Child marriage is also a form of coercion for girls to physically or psychologically take responsibility where their condition is not ready. Thus, child marriages take the form of violations of children's rights, especially girls who in the Marriage Law are allowed to have marriages if they have reached 16 years of age or are still underage. For this vulnerability, the state has protected through Article 28B paragraph (2) of the 1945 Constitution and is further elaborated by Law No. 23 of 2002 concerning Child Protection.

At least, the rights violated in child marriages are the right to growth and development, the right to education, the right to livelihood, socio-political rights, the right to be free from violence. For example, the cessation of the right to education will also cease to have a decent living right when only the husband makes a living because women (only Junior High School graduates) are not ready to compete in the labor market.

Letting girls marry before the age of 18 is the same as eliminating guarantees for girls to be free from violence and discrimination. This is the same as expanding the number of women who are victims of domestic violence in the form of physical, psychological, sexual violence, or economic neglect.

Furthermore, the purpose of child marriage is not following Marriage's purpose as stipulated in the law. The purpose of marriage has been regulated in Law Number 1 of 1974 is "to form a happy or eternal family or family based on the supreme divinity". The purpose of this marriage, according to Act No. 1 of 1974 , is that marriage forms a happy and eternal household. This means that marriage is expected to last a lifetime and not end like that. To form a happy and eternal family must be based on the supreme divinity.

Marriage is done not only as a fulfillment of biological needs, but Marriage is also a birth and inner bond between a man and a woman. That is, between husband and wife couples, a bond can be seen, which is a legal bond. Furthermore, spiritual ties mean that a husband and wife partner has a bond 
that the husband and wife's partner can only feel, and the bond cannot be seen. Birth and mental ties must always be closely coupled to create a happy family.

$\mathrm{R}$. Wirjono Prodjodikoro even emphasized that: "Marriage is a legitimate bond to foster happy, prosperous households and families where both husband and wife carry the mandate and responsibility; therefore the wife will experience a psychotic process, namely pregnancy, and childbirth, which asks for sacrifice"19

It has been stated that a husband and wife partner in a family will carry the trust and responsibility they will endure for the rest of their lives or during the marriage. Immature people of thought cannot fulfill the mandate and heavy responsibility. Physical and emotional will also be challenging to hold the mandate and responsibility. A happy marriage must be lived with careful preparation financially, physically, and emotionally. ${ }^{20}$

Furthermore, international conventions have also been ratified by Indonesia in this regard. In 2005, Indonesia ratified the International Covenant on Civil and Political Rights through Law No. 12 of 2005. The significant meaning of this ratification is that Indonesia recognizes two conventions considered the parent of various other international convention instruments in human rights. Another essential element is that there is no reservation by the Indonesian state on the two covenants except for the right to selfdetermination.

The Convention on the Rights of the Child (CRC) is an integral part of universal human rights instruments. The CRC contains detailed human rights for each child, including the right to survival, the right to growth (development, the right to protection), and the right to be involved and participate in life. The CRC has four general principles that further illustrate the fundamental rights mentioned above. The four principles are: a) Non-discrimination means that every right that exists and is recognized in the CRC must be applied to every child without discrimination on any basis, b) The best interest of children, namely that all actions are carried out by persons with obligations (duty bearers); that is, all government agencies, whether executive, legislative or

${ }^{19}$ R. Wirjono Prodjodikoro, Hukum Perkawinan di Indonesia (Bandung: Sumur Bandung, 1991); Alvan Fathoni, "Perkawinan Anak di Bawah Umur dalam Perspektif Hukum Islam dan Sosiologi Hukum," At-Turas: Jurnal Studi Keislaman 4, no. 1 (2017): 69-84, https://doi.org/ 10.33650/at-turas.v4i1.197.

${ }^{20}$ Prodjodikoro, Hukum Perkawinan di Indonesia. 
judicial, as well as the private sector and society as a whole) must be in the best interests of the child as their necessary consideration, c) Right to life, survival, and development (right to life, survival, and development); means that all parties must recognize that every child has the right to adhere to life, and therefore must also ensure the maximum survival and development of the child both physically and mentally, d) Respect for the child's views; means that children's opinions, especially when it comes to matters that affect their lives, must also be considered in every decision making. This also means that children are not objects that can be treated arbitrarily.

\section{Social Aspect of Underage Marriage: What Causes it, and How can this Happen?}

Underage marriage is a marriage carried out below the age limit set out in Law No. 1 of 1974 concerning Marriage, where women may marry when they reach 16 years and men have reached 19 years. Under the prescribed age limit, children may only conduct marriages if they have received a dispensation from the court. Marriage dispensation is a permit from the district court to marry so that the marriage is a legal state. It is widely known that child marriage is related to tradition and culture, making it difficult to change. Economic reasons, hopes of achieving social and financial security after marriage cause many parents to encourage their children to marry at a young age. ${ }^{21}$

One of the driving factors that make girls drop out of school is because they believe that women are good if married at a young age. ${ }^{22}$ The still healthy patriarchal thinking makes parents want to marry off their daughters immediately because education is no longer considered necessary because women will only follow, take care of their husbands, cook in the kitchen, clean the house, and other things that are still attached to the views of ancient people and village people to women with wife status.

Although the definition of underage marriage is also intended for boys, most children who are married under the age of 18 are women, even though the practice of underage marriage globally has fallen dramatically in the last 30

\footnotetext{
${ }^{21}$ Inna Noor Inayati, "Perkawinan Anak di Bawah Umur dalam Perspektif Hukum, HAM dan Kesehatan," Jurnal Bidan "Midwife Journal” 1, no. 1 (2015): 46-53.

${ }^{22}$ Maidin Gultom, Perlindungan Hukum terhadap Anak dan Perempuan (Bandung: Refika Aditama, 2012).
} 
years. However, in low or not prosperous community groups, underage marriage is still prevalent. ${ }^{23}$ Given that children's marriages are the most common among the poor and traditional people arrangement, the observation that young married women have less average education does not mean forcing women to delay. 24

In the case of underage marriages, most marriages can occur due to coercion from parents. Forcing someone to get married includes crime. Forced Marriage is different from an arranged marriage. In an arranged marriage, someone can refuse if they do not want to marry the person they arranged. Nevertheless, if a marriage is forced, someone cannot refuse and reluctantly must do it. Forced marriage is usually done because of business, to preserve cultural traditions, and to improve the family economy. ${ }^{25}$

In the same context, it is also emphasized that problems in the household will indeed exist, and for some households, it will often occur. Some married husbands and wives are already mature in emotional and financial matters, but some married couples and wives, after five years of marriage will face various kinds of problems that hit household life. ${ }^{26}$ In this case, underage marriage has more problems.

Child marriage is prevalent today and has substantial negative development impacts in education, labor force participation, health, violence, and empowerment. ${ }^{27}$ Many underage marriages lead to divorce because the bride and groom at the beginning of the marriage are beginning to falter in their household problems. ${ }^{28}$ Because there is no physical maturity either

\footnotetext{
${ }^{23} Y$ usuf Hanafi, “Perkawinan Anak di Bawah Umur dalam Perspektif Hukum Islam,” Ulumuna: Journal of Islamic Studies 12, no. 2 (2008): 249-74, https://doi.org/10.20414/ujis.v12i2.381.

${ }^{24}$ Erica Field and Attila Ambrus, "Early Marriage, Age of Menarche, and Female Schooling Attainment in Bangladesh," Journal of Political Economy 116, no. 5 (2008): 881-930, https://doi.org/10.1086/593333.

${ }^{25}$ Ambika Kohli, "Forced and Underage Marriages in New Zealand: Some Reflections on Public and Private Patriarchy and Intersectionality," International Journal for Intersectional Feminist Studies 1, no. 1 (2015): 58-70, https://doi.org/10.26021/770.

26Zadrian Ardi and Nining Maizura, "The Psychological Analysis of Divorce at Early Marriage," International Journal of Research in Counseling and Education 1, no. 3 (2018): 77-82, https://doi.org/10.24036/0026za0002.

${ }^{27}$ Minh Cong Nguyen and Quentin Wodon, "Global and Regional Trends in Child Marriage," The Review of Faith \& International Affairs 13, no. 3 (2015): 6-11, https://doi.org/10.1080/15570274. 2015.1075756.

${ }^{28}$ Mawardi, “Problematika Perkawinan di Bawah Umur."
} 
psychologically in the underage couple. Maturity is closely related to age, so that age is not enough and is still considered young, not necessarily enough maturity to deal with problems that will occur in the household ark. Households are expected to be happy and intact until the end of their lives. It will be challenging to create if the husband and wife cannot manage it properly. Child marriage will endanger children's survival and growth and place children in situations prone to violence and discrimination ${ }^{29}$

Child marriage has consequences such as gender inequality. The bride has fewer opportunities to voice opinions, signify the desire to have sex, use contraception, and conceive children. The dominance of couples often causes children to be vulnerable to domestic violence. Children who get domestic violence often do not resist, so they do not have security in social and financial fields. Also, marriages with couples linked to their age increase the risk of the family becoming incomplete due to divorce or widows because the spouse dies. ${ }^{30}$

They face challenges in shaping their adult identity at the same time when they are asked to bear the duties of a wife and a mother, which can create a lot of pressure. ${ }^{31}$ In problems that occur in the household usually, the women are often harmed.

There are times when each partner will face problems related to the economy. Especially at a young age, not much is expected in terms of the economy. At a young age, work is still unclear, so that there will be economic difficulties that married couples will face. Usually, when a husband and wife fail to take care of economic problems, they choose to divorce, and the woman will be returned to her parents. In psychological problems, of course, minors are not mature enough and wise to manage the household. Convoluted household problems will be challenging to pass correctly if the husband and wife's mentality is nothealthy.

We should know that pregnancies under 17 increase medical complications in both mother and child in terms of health. ${ }^{32}$ Underage women

\footnotetext{
${ }^{29}$ Mawardi.

${ }^{30}$ Eddy Fadlyana and Shinta Larasaty, "Pernikahan Usia Dini dan Permasalahannya," Sari Pediatri 11, no. 2 (2016): 136-41, https://doi.org/10.14238/sp11.2.2009.136-41.

${ }^{31}$ Dorit Segal-Engelchin, Efrat Huss, and Najlaa Massry, "The Experience of Early Marriage: Perspectives of Engaged and Married Muslim Women in Israel," Journal of Adolescent Research 31, no. 6 (2015): 725-49, https://doi.org/10.1177/0743558415605167.

32Fadlyana and Larasaty, "Pernikahan Usia Dini dan Permasalahannya."
} 
marry more of a health threat due to pregnancy and childbirth at a young age. Things that need attention in the case of early marriage are complications that occur during pregnancy and childbirth where will cause the child to be born and possibly at risk and contribute to an increase in mortality rates for the mother and her baby. Children born from early marriage also have many problems. When a child is still growing undergoes a pregnancy process, there is healthy competition with the fetus he contains. The weight of pregnant women is difficult to rise, can be accompanied by anemia due to nutritional deficiencies, and the risk of giving birth to babies with low birth weight. It was found that around $14 \%$ of babies born to mothers under 17 years were premature. The age at first sexual intercourse will also increase the risk of sexually transmitted diseases and HIV transmission. Many children who carry out underage marriages do not yet understand the essential reproductive health, including the risk of getting HIV infection.

If you carry out Marriage only based on love and not careful preparation, do not think of other things needed when living together as a married couple. People who are not mature in thinking are usually already married, just because they already have the same feelings and have fallen in love. Then they are sure to live happily ever after because of that love. Even though family life is not just a matter of feeling. Feelings are not vital to decide that a couple is ready to do a marriage. Because of this irrational thinking, there are many weaknesses and problems experienced in the family.

Regarding the age limit, a woman cannot get married if she has not reached 16 (sixteen) years. At the age of 16, a woman is considered mature in thinking and ready to live life as a wife and mother. However, at the age of 16 , they were not ready to live a wife and mother's life. Sixteen years old should still attend education at the High School level. Because of their Marriage, they did not continue their education until it was finished, and this had robbed her of the rights to education.

In the marriage provisions stipulated in the Criminal Code, the age limit for women is 16 years, and men's age limit is 19 years. However, deviations from the age limit can occur due to the court's marriage dispensation or other designated officials. Parents of both men and women can submit dispensation requests. In article 6, paragraphs (1) and (2), the Law on Marriage also stipulates that marriage must be based on parental permission if it has not 
reached 21 years. The existence of a marriage dispensation has the goal of preventing larger problems so that legislation can be said to be more flexible so as not to cause more severe problems. ${ }^{33}$

\section{Education Rights for Underage Married Women: How are These Rights Protected?}

Children need attention from the home environment supported by friendly, strict people and a sound health system to help them grow and become healthy women for family, community, and country development. ${ }^{34}$ Children are valuable future generation assets. It can be concluded that its carrier's hands determine the good or bad of a nation's future. In this case, the child is grasped by the future of the people. ${ }^{35}$ Children who are being nurtured by their parents now will play an important role when they grow up. Therefore, if parents do not attach importance to education for their children, they cannot learn and develop well for their future.

Although education has been unanimously endorsed as a fundamental right and a clear development goal, access to schools remains inadequate in some parts of the developing world. ${ }^{36}$ Education is one of the essential things that allow women to assert their fundamentals, train women wisely, and expand their ideas. Knowing something only for the sake of knowledge is intrinsically vital in education. ${ }^{37}$

Age education and awareness are critical, and the role of parents and extended family plays a large role in marrying girls who are not old enough to get married. ${ }^{38}$ Education is also one of the fundamental things that allow

${ }^{33}$ Ali Imron, “Dispensasi Perkawinan Perspektif Perlindungan Anak," Qistie: Jurnal Ilmu Hukum 5, no. 1 (2011): 69-90, https://doi.org/10.31942/jqi.v5i1.601.

${ }^{34}$ Amruta Swati Indupalli and Siddesh Basavaraj Sirwar, "A Cross Sectional Study on Demographic Profile and Role of Education Inadolescent Girls," People's Journal of Scientific Research 4, no. 1 (2011): 19-22.

${ }^{35}$ Tatik Mei Widari, "Pemenuhan Hak Pendidikan Anak Didik Pemasyarakatan di Lembaga Pemasyarakatan Anak," DiH: Jurnal Ilmu Hukum 8, no. 15 (2012): 28-47, https://doi.org/ 10.30996/dih.v8i15.261.

${ }^{36}$ T. Castro Martín, "Women's Education and Fertility: Results from 26 Demographic and Health Surveys.," Studies in Family Planning 26, no. 4 (1995): 187-202.

37Ingrid Robeyns, "Three Models of Education," Theory and Research in Education 4, no. 1 (2006): 69-84, https://doi.org/10.1177/1477878506060683.

${ }^{38}$ Alexia Sabbe et al., "Determinants of Child and Forced Marriage in Morocco: Stakeholder Perspectives on Health, Policies and Human Rights," BMC International Health and Human Rights 13, no. 1 (2013): 43, https://doi.org/10.1186/1472-698X-13-43. 
women to assert their fundamental rights, train women wisely, and work to expand their ideas. Women have rights to themselves, which are often underestimated by other people, even though women have no rights. This is compounded because women do not have equal opportunities to get an education. Therefore, they do not get their rights properly. In other words, gender bias occurs and often occurs in social, class, and affiliate status, ${ }^{39}$ including gender bias in education.

Early marriage causes underage women to lose their opportunity to get a higher education, lose their teenagers' desires and create dependence on other people economically and socially. ${ }^{40}$ Parents' initial goal is to marry their underage children to foster their household and take care of their lives and their own families. Still, in the end, their children depend on others because of economic factors that are not enough to nurture their families.

Every girl has the right to obtain education and teaching in the context of her personal development following her interests, talents, and level of intelligence. ${ }^{41}$ Children have the best times to develop their personality from their interests, develop their talents, and level intelligence in school. Education is essential for children because education can be a child's capital to continue their future and improve their deviant behavior patterns. ${ }^{42}$

Every child who is married underage will undoubtedly drop out of school. Very few children continue to study after getting married, meaning children will lose their access to education. ${ }^{43}$ In Indonesia, married children are not allowed to take formal education in school. The reason is, if a married child is allowed to marry, then the latent function of the educational institution cannot be carried out. The latent function is a hidden function of educational institutions. One of

\footnotetext{
${ }^{39}$ Michele Goodwin, "When Institutions Fail: The Case of Underage Marriage in India," DePaul Law Review 62, no. 2 (2013): 357.

${ }^{40}$ Inayah Rohmaniyah, "Konstruksi Seksualitas dan Relasi Kuasa dalam Praktik Diskursif Pernikahan Dini," Musãwa Jurnal Studi Gender dan Islam 16, no. 1 (n.d.): 33, https://doi.org/ 10.14421/musawa.2017.161.33-52.

${ }^{41}$ H. R. Abdussalam and Adri Desasfuryanto, Hukum Perlindungan Anak(Jakarta: PTIK, 2016).

${ }^{42}$ Mies Grijns and Hoko Horii, "Child Marriage in a Village in West Java (Indonesia): Compromises between Legal Obligations and Religious Concerns," Asian Journal of Law and Society 5 , no. 2 (2018): 453-66, https://doi.org/10.1017/als.2018.9.

${ }^{43}$ Rohmaniyah, "Konstruksi Seksualitas dan Relasi Kuasa dalam Praktik Diskursif Pernikahan Dini"; Mawardi, "Problematika Perkawinan di Bawah Umur"; Rahmatian, "Studi Kasus Perkawinan di Bawah Umur."
} 
the latent functions of educational institutions is to extend adolescence so that children do not want to get married quickly. Nevertheless, in reality, many children prefer to drop out of school (forced and willing) because they prefer to get married.

The education of a girl can be disrupted even to the point where she cannot continue her education when she is married, thus limiting her ability to grow even more so that there are fewer job opportunities. Not surprisingly, a woman underage married is more likely to live in poverty when she lives. The risk of domestic violence and divorce is also higher. Underage married women tend to have many children, and the age gap between one child and another will be closer. ${ }^{44}$

Married children can continue their education, and there is no prohibition on married children not continuing their education. However, married children may only continue non-formal education or take part in an equality program. However, in reality, education is no longer a fundamental right for married girls. Lack of education from parents, environmental conditions, and the patriarchal culture that is still thick in Indonesia, some people assume that education is not essential for women. The more significant issue is that children's marriage under age is more likely to involve girls than boys. ${ }^{45}$ They were launched by a patriarchal community that is still rife in Indonesia.

It is not difficult to find a woman who only devotes her entire life to just taking care of home affairs, not working outside, and devoting herself only to her husband and children. The women-only cooks' busyness in the kitchen, thinking about what food will be made for breakfast, afternoon and evening, shopping, cleaning the house so that the golden triangle appears for women, namely "kitchen, mattress, and well". 46 The case of married girls deprives them of the good times in their playing age and injures the spirit of justice and harmony of the household. ${ }^{47}$ Education affects underage marriages because

\footnotetext{
${ }^{44}$ Nour, "Child Marriage: A Silent Health and Human Rights Issue."

${ }^{45}$ Paul Scott Prettitore, "Family Law Reform, Gender Equality, and Underage Marriage: A View from Morocco and Jordan," The Review of Faith \& International Affairs 13, no. 3 (2015): 32-40, https://doi.org/10.1080/15570274.2015.1075758.

${ }^{46}$ Hamzah Hasan, "Pernikahan di Bawah Umur (Analisis tentang Konsekuensi Pemidanaan)," Al-Daulah: Jurnal Hukum Pidana dan Ketatanegaraan 6, no. 1 (2017): 86-120, https://doi.org/10.24252/ad.v6i1.4869.

47Moh. Roqib, “Pernikahan Dini dan Lambat: Merampas Hak-Hak Anak," Yin Yang: Jurnal Studi Gender dan Anak 5, no. 2 (2010): 296-311.
} 
higher education is more likely to be associated with lower education, the possibility of consumption is delayed marriage, and the possibility of a mother being a lower mother.48

\section{E. Conclusion}

This paper highlighted and concluded that the issue of child marriage is one of the biggest in Indonesia. Although it regulates the age limit of couples who want to get married, marriage law still opens the opportunity to legitimize child marriage through marriage dispensation. In fact, according to the UN, the International Convention, and various research studies, that child marriage in many cases violates the rights of children within the framework of human rights. Besides, the case of child marriage also shows the government's failure in providing appropriate protection for children. Weak legal rules make child marriage rife in Indonesia. Although the perpetrators of child marriages can be charged with many criminal cases, get court approval through marriage dispensation. Social factors that cause child marriage are rife, including economic, socio-cultural, religious, and educational levels.[s]

\section{References}

Abdussalam, H. R., and Adri Desasfuryanto. Hukum Perlindungan Anak. Jakarta: PTIK, 2016.

Ardi, Zadrian, and Nining Maizura. "The Psychological Analysis of Divorce at Early Marriage." International Journal of Research in Counseling and Education 1, no. 3 (2018): 77-82. https://doi.org/10.24036/0026za0002.

Candraningrum, Dewi. "Pernikahan Anak: Status Anak Perempuan." Jurnal Perempuan 21, no. 1 (2016): 4-8.

Choe, Minja Kim, Shyam Thapa, and Vinod Mishra. "Early Marriage and Early Motherhood in Nepal." Journal of Biosocial Science 37, no. 2 (2005): 143-62. https://doi.org/10.1017/S0021932003006527.

Editor Kompas. "Pernikahan Dini, Bentuk Pelanggaran HAM.” Kompas, January 28, 2009.

${ }^{48}$ Minja Kim Choe, Shyam Thapa, and Vinod Mishra, "Early Marriage and Early Motherhood in Nepal," Journal of Biosocial Science 37, no. 2 (2005): 143-62, https://doi.org/10.1017/ S0021932003006527. 
https://internasional.kompas.com/read/2009/01/28/19315957/Pernikahan.D ini.Bentuk.Pelanggaran.HAM.

Fadlyana, Eddy, and Shinta Larasaty. "Pernikahan Usia Dini dan Permasalahannya." Sari Pediatri 11, no. 2 (2016): 136-41. https://doi.org/10.14238/sp11.2. 2009.136-41.

Fahlevi, Reza. "Aspek Hukum Perlindungan Anak dalam Prespektif Hukum Nasional." Lex Jurnalica 12, no. 3 (2015): 177-91.

Fathoni, Alvan. "Perkawinan Anak di Bawah Umur dalam Perspektif Hukum Islam dan Sosiologi Hukum." At-Turas: Jurnal Studi Keislaman 4, no. 1 (2017): 69-84. https://doi.org/10.33650/at-turas.v4i1.197.

Field, Erica, and Attila Ambrus. "Early Marriage, Age of Menarche, and Female Schooling Attainment in Bangladesh." Journal of Political Economy 116, no. 5 (2008): 881930. https://doi.org/10.1086/593333.

Goodwin, Michele. "When Institutions Fail: The Case of Underage Marriage in India." DePaul Law Review 62, no. 2 (2013): 357.

Grijns, Mies, and Hoko Horii. "Child Marriage in a Village in West Java (Indonesia): Compromises between Legal Obligations and Religious Concerns." Asian Journal of Law and Society 5, no. 2 (2018): 453-66. https://doi.org/10.1017/als.2018.9.

Gultom, Maidin. Perlindungan Hukum terhadap Anak dan Perempuan. Bandung: Refika Aditama, 2012.

Gunadha, Reza. "Perempuan di Jawa Tengah Rata-Rata Nikah Usia 12 Tahun," September 16, 2018. https://www.suara.com/news/2018/09/16/165232/ perempuan-di-jawa-tengah-rata-rata-nikah-usia-12-tahun.

Hanafi, Yusuf. "Perkawinan Anak Di Bawah Umur Dalam Perspektif Hukum Islam." Ulumuna: Journal of Islamic Studies 12, no. 2 (2008): 249-74. https://doi.org/ 10.20414/ujis.v12i2.381.

Hasan, Hamzah. "Pernikahan di Bawah Umur (Analisis tentang Konsekuensi Pemidanaan)." Al-Daulah: Jurnal Hukum Pidana dan Ketatanegaraan 6, no. 1 (2017): 86-120. https://doi.org/10.24252/ad.v6i1.4869.

Imron, Ali. "Dispensasi Perkawinan Perspektif Perlindungan Anak." Qistie: Jurnal Ilmu Hukum 5, no. 1 (2011): 69-90. https://doi.org/10.31942/jqi.v5i1.601.

Inayati, Inna Noor. "Perkawinan Anak di Bawah Umur Dalam Perspektif Hukum, HAM dan Kesehatan." Jurnal Bidan "Midwife Journal" 1, no. 1 (2015): 46-53.

Indupalli, Amruta Swati, and Siddesh Basavaraj Sirwar. "A Cross Sectional Study on Demographic Profile and Role of Education Inadolescent Girls." People's Journal of Scientific Research 4, no. 1 (2011): 19-22. 
Jensen, Robert, and Rebecca Thornton. "Early Female Marriage in the Developing World." Gender \& Development 11, no. 2 (2003): 9-19. https://doi.org/ 10.1080/741954311.

Kohli, Ambika. "Forced and Underage Marriages in New Zealand: Some Reflections on Public and Private Patriarchy and Intersectionality." International Journal for Intersectional Feminist Studies 1, no. 1 (2015): 58-70. https://doi.org/10.26021/ 770.

Koro, Abdi. Perlindungan Anak di Bawah Umur dalam Perkawinan Usia Muda dan Perkawinan Siri. Bandung: Alumni, 2012.

Layla, Ida Nur. "Satu dari Lima Anak di Jateng Nikah Dini." Radar Semarang, October 14, 2019. https://radarsemarang.jawapos.com/berita/semarang/2019/10/14/ satu-dari-lima-anak-di-jateng-nikah-dini-3/.

Martín, T. Castro. "Women's Education and Fertility: Results from 26 Demographic and Health Surveys." Studies in Family Planning 26, no. 4 (1995): 187-202.

Mawardi, Marmiati. "Problematika Perkawinan di Bawah Umur." Analisa 19, no. 2 (2012): 201-12. https://doi.org/10.18784/analisa.v19i2.166.

Mediani, Mesha. "Pernikahan Dini dan Persoalan Hak Anak yang tak Terlindungi." CNN Indonesia, April 18, 2018. https://www.cnnindonesia.com/nasional/ 20180418100224-20-291626/pernikahan-dini-dan-persoalan-hak-anak-yangtak-terlindungi.

Nguyen, Minh Cong, and Quentin Wodon. "Global and Regional Trends in Child Marriage." The Review of Faith \& International Affairs 13, no. 3 (2015): 6-11. https://doi.org/10.1080/15570274.2015.1075756.

Nour, Nawal M. "Child Marriage: A Silent Health and Human Rights Issue." Reviews in Obstetrics \& Gynecology 2, no. 1 (2009): 51-66.

Nurhidayatuloh, Nurhidayatuloh, and Leni Marlina. "Perkawinan di Bawah Umur Perspektif HAM: Studi Kasus di Desa Bulungihit, Labuhan Batu, Sumatra Utara." Al-Mawarid Journal of Islamic Law11, no. 2 (2011): 211-24.

Prettitore, Paul Scott. "Family Law Reform, Gender Equality, and Underage Marriage: A View from Morocco and Jordan." The Review of Faith \& International Affairs 13, no. 3 (2015): 32-40. https://doi.org/10.1080/15570274.2015.1075758.

Prodjodikoro, R. Wirjono. Hukum Perkawinan di Indonesia. Bandung: Sumur Bandung, 1991.

Radar Pekalongan. "Angka Pernikahan Dini di Kota Santri Rangking Tiga se-Jateng." Radar Pekalongan, April 1, 2019. https://radarpekalongan.co.id/65767/angkapernikahan-dini-di-kota-santri-rangking-tiga-se-jateng/. 
Rahmatian, Rahmatian. "Studi Kasus Perkawinan di Bawah Umur." Al-Daulah: Jurnal Hukum Pidana dan Ketatanegaraan 5, no. 1 (2016): 119-132. https://doi.org/ 10.24252/ad.v5i1.1447.

Robeyns, Ingrid. “Three Models of Education." Theory and Research in Education 4, no. 1 (2006): 69-84. https://doi.org/10.1177/1477878506060683.

Rohmaniyah, Inayah. "Konstruksi Seksualitas dan Relasi Kuasa dalam Praktik Diskursif Pernikahan Dini." Musãwa Jurnal Studi Gender dan Islam 16, no. 1 (2017): 33. https://doi.org/10.14421/musawa.2017.161.33-52.

Roqib, Moh. "Pernikahan Dini dan Lambat: Merampas Hak-Hak Anak." Yin Yang: Jurnal Studi Gender Dan Anak5, no. 2 (2010): 296-311.

Sabbe, Alexia, Halima Oulami, Wahiba Zekraoui, Halima Hikmat, Marleen Temmerman, and Els Leye. "Determinants of Child and Forced Marriage in Morocco: Stakeholder Perspectives on Health, Policies and Human Rights." BMC International Health and Human Rights 13, no. 1 (2013): 43. https://doi.org/ 10.1186/1472-698X-13-43.

Saputri, Maya. "KPPPA: Satu Dari Enam Anak Perempuan Indonesia Menikah Usia Dini." tirto.id. Tirto, September 19, 2019. https://tirto.id/kpppa-satu-dari-enamanak-perempuan-indonesia-menikah-usia-dini-ehS4.

Saraswati, Rika. "Hukum Perlindungan Anak di Indonesia." Bandung: Citra Aditya Bakti, 2015.

Segal-Engelchin, Dorit, Efrat Huss, and Najlaa Massry. "The Experience of Early Marriage: Perspectives of Engaged and Married Muslim Women in Israel." Journal of Adolescent Research 31, no. 6 (2015): 725-49. https://doi.org/10.1177/ 0743558415605167.

Setiaji, Mukhamad Luthfan, and Aminullah Ibrahim. "Kajian Hak Asasi Manusia Dalam Negara the Rule of Law: Antara Hukum Progresif Dan Hukum Positif." Lex Scientia 2, no. 2 (2018): 123-38. https://doi.org/10.15294/lesrev.v2i2.27580.

Sulaiman, M. Reza, and Risna Halidi. "Perkawinan Anak, Catatan Hitam di Hari Anak Perempuan Internasional 2019." suara.com, October 11, 2019. https://www. suara.com/health/2019/10/11/061500/perkawinan-anak-catatan-hitam-dihari-anak-perempuan-internasional?page=all.

Syahrianto, Muhammad. "Belum Turun, Jumlah Perkawinan Anak di Indonesia masih di Angka 193 Ribu Kasus." Warta Ekonomi, February 1, 2020. https://www. wartaekonomi.co.id/read269607/belum-turun-jumlah-perkawinan-anak-diindonesia-masih-di-angka-193-ribu-kasus;

Tati, Susi Dwi Maret, and Sofwan Indarjo. "Partisipasi Pasangan Pernikahan Dini terhadap Program Keluarga Berencana." Higeia (Journal of Public Health Research and Development) 1, no. 2 (2017): 65-76. 
Ridwan Arifin, Rodiyah, Fadhilah Rizky Afriani Putri

Widari, Tatik Mei. "Pemenuhan Hak Pendidikan Anak Didik Pemasyarakatan di Lembaga Pemasyarakatan Anak" DiH: Jurnal Ilmu Hukum 8, no. 15 (2012): 2847. https://doi.org/10.30996/dih.v8i15.261.

Zuraya, Nidia. "KPI: Kasus Perkawinan Anak di Jateng Tinggi." republika.co.id, November 20, 2017. https://www.republika.co.id/berita/nasional/daerah/ 17/11/20/ozq2z7383-kpi-kasus-perkawinan-anak-di-jateng-tinggi. 